\title{
Evaluation of an LED Retrofit Project at Princeton University's Carl Icahn Laboratory
}

Prepared for:

Commercial Building Integration Building Technologies Office Office of Energy Efficiency and Renewable Energy U.S. Department of Energy

\section{Prepared by:}

Pacific Northwest National Laboratory 
PNNL-24526

\title{
DISCLAIMER
}

This report was prepared as an account of work sponsored by an agency of the United States Government. Neither the United States Government nor any agency thereof, nor Battelle Memorial Institute, nor any of their employees, makes any warranty, express or implied, or assumes any legal liability or responsibility for the accuracy, completeness, or usefulness of any information, apparatus, product, or process disclosed, or represents that its use would not infringe privately owned rights. Reference herein to any specific commercial product, process, or service by trade name, trademark, manufacturer, or otherwise does not necessarily constitute or imply its endorsement, recommendation, or favoring by the United States Government or any agency thereof, or Battelle Memorial Institute. The views and opinions of authors expressed herein do not necessarily state or reflect those of the United States Government or any agency thereof.

\author{
PACIFIC NORTHWEST NATIONAL LABORATORY \\ operated by \\ BATTELLE \\ for the \\ UNITED STATES DEPARTMENT OF ENERGY \\ under Contract DE-AC05-76RL01830
}

Printed in the United States of America
Available to DOE and DOE contractors from the Office of Scientific and Technical Information, P.O. Box 62, Oak Ridge, TN 37831-0062;
ph: (865) 576-8401
fax: $(865) 576-5728$
email: reports@adonis.osti.gov

Available to the public from the National Technical Information Service 5301 Shawnee Rd., Alexandria, VA 22312

ph: (800) 553-NTIS (6847)

email: orders@ntis.gov <http://www.ntis.gov/about/form.aspx>

Online ordering: http://www.ntis.gov

This document was printed on recycled paper. 


\section{Evaluation of an LED Retrofit Project at Princeton University's Carl Icahn Laboratory}

Final Report prepared in support of the Commercial Building Integration Program

Robert Davis ${ }^{1}$

Arthur Murphy ${ }^{2}$

Tess Perrin ${ }^{3}$

November 2015

Prepared for:

U.S. Department of Energy

under Contract DE-AC05-76RL01830

Pacific Northwest National Laboratory

Richland, Washington 99352

Pacific Northwest National Laboratory

Princeton University Facilities Engineering

Pacific Northwest National Laboratory 


\section{Preface}

The U.S. DOE conducts demonstration projects documenting the performance of LED luminaires relative to conventional technologies to increase market adoption of energy-efficient LED systems and to stimulate ongoing product development. These demonstration projects evaluate various aspects of lighting design, purchase, installation, and operation, and they assess the impacts LED technology might have on building owners and users. DOE collaborates with building owners and managers in these demonstrations and evaluates projects based on the general criteria of saving energy, matching or improving lighting quality, and offering cost-effective solutions relative to standard competing light sources.

This report focuses on documenting the implementation of LED retrofit products in Princeton University's Carl Icahn Laboratory of the Lewis-Sigler Institute for Integrative Genomics.

\section{Acknowledgements}

William Evans, PE, Electrical Engineer with Facilities Engineering at Princeton, provided important support throughout this project, especially during the data collection visits to the facility. His contributions are gratefully acknowledged. 


\section{Executive Summary}

Princeton University is the fourth-oldest college in the United States and is home to about 6,000 employees and nearly 8,000 students. The university's main campus in Princeton, NJ consists of approximately 180 buildings occupying nine million square feet of space on 500 acres. While the University has implemented many exterior lighting projects and a few smaller interior projects, the Carl Icahn Laboratory of the Lewis-Sigler Institute for Integrative Genomics is the first building-wide interior LED project. The Carl Icahn Laboratory is a 98,000 square foot facility, with two separate three-story wings (a basement level plus two above-ground levels) that are connected by a curving, two-story atrium space.

Most of the original lighting in the laboratory and office spaces consisted of recessed $2 \times 2$ fluorescent troffers, with supplemental linear fluorescent cove lighting in perimeter areas and a relatively small number of recessed $2 \times 4$ fluorescent troffers. Of the $564,000 \mathrm{kWh}$ of energy used annually for lighting in the facility, about $43 \%$ was from the $2 \times 2$ fixtures and $30 \%$ from the 4 ' linear lamp fixtures. The third largest lighting energy use came from recessed and surface-mounted downlights using compact fluorescent lamps (CFLs); these luminaires were used in lobby and corridor areas and accounted for about $18 \%$ of the lighting energy used in the facility.

Because of the age and operations of the lighting systems in the Carl Icahn Laboratory, an upgrade to the incumbent systems provided several important opportunities for Princeton:

- Energy savings and the associated carbon reduction.

- Maintenance and operational cost savings.

- Implementation of intelligent controls for occupancy and dimming.

- Improvements in lighting quality.

The LED retrofit project at the Carl Icahn Laboratory addressed each of these opportunities in the three primary luminaire types by replacing the incumbent fluorescent lamps with LED retrofit products. For the $8152 \times 2$ luminaires, the Princeton facilities engineering staff evaluated retrofit products from five different manufacturers, then based on an initial evaluation of performance, price, and warranty, three of the products were selected for further assessment. Multiple samples of those products were installed in the building, where they were evaluated by various stakeholders for such considerations as appearance, perceived impacts on light levels and distribution, and potential glare. The outcome of this evaluation process was the selection of a MaxLite ${ }^{\circledR}$ LED retrofit kit that provides 3315 lumens at $45 \mathrm{~W}$ power input, with a CCT of $4100 \mathrm{~K}$ and minimum CRI of 82 .

For the cove and other luminaires using linear T8 fluorescent lamps, more than 550 luminaires were retrofitted with the Cree UR Series retrofit kit that replaces the lamps and ballasts, providing 4500 lumens at $44 \mathrm{~W}$ input power, with a CCT of $4000 \mathrm{~K}$ and a CRI of 80 . Each kit replaces two T8 lamps. The facilities engineering staff selected the UR Series product based on favorable experiences in several prior small-scale retrofit projects in other buildings on campus.

The most common downlight in the facility used two 42 W CFLs, which posed a challenge for LED retrofit products due to the relatively high light output (each CFL is rated to produce 3200 lumens). Princeton evaluated several options for these luminaires through mock-ups and review of technical information, with most of the alternates failing to meet the light output requirements. Ultimately, the TerraLux DR8 retrofit kit was selected, and two other TerraLux products were then selected for the other, lower light output downlights in the facility. The LED retrofit solutions were installed in 245 downlights. 
In addition, the conversion to LED enabled more extensive use of lighting controls to tailor the lighting to the task and limit the operating hours based on occupancy. The incumbent recessed $2 \times 2$ and cove luminaires in the open lab spaces were controlled by relatively few wall switches that control large zones of luminaires. Princeton decided to implement wireless occupancy sensor controls that would address smaller zones of luminaires, enabling further energy savings through dimming or turning off luminaires in zones where there was no occupancy detected. The occupancy sensors were also integrated with the building's HVAC system, extending the energy savings by also reducing the HVAC energy use during periods of low or no occupancy. In addition to the occupancy-based lighting controls, the ability to dim the LED retrofit kits for the $2 \times 2$ luminaires enabled further savings by allowing the illuminance levels in spaces to be adjusted to meet specific task needs. At the time of this report, although all of the LED retrofit products had been installed and operational for several months, the control system had not yet been completely deployed and commissioned.

Table ES1 shows the estimated energy savings for the facility, with the additional savings expected from full implementation of the controls strategies. As shown, the estimated energy savings including controls is $62 \%$ compared to the incumbent system. Because the $2 \times 2$ troffers are used throughout areas where the controls strategies are implemented, this luminaire type has the greatest additional savings from controls. The other luminaire types are used in some application areas where the controls are implemented and in other areas where the existing controls remain in place, so the estimated additional savings were only applied to the relevant areas. Although the specific costs and financial details of the project are confidential, the project is expected to yield a simple payback of less than four years. Additionally, the energy savings from the lighting retrofit is estimated to avoid about 100 metric tons of carbon dioxide emissions, an important consideration in Princeton's energy management efforts.

Table ES1: Estimated energy savings for the LED retrofit project at the Carl Icahn Laboratory, including reductions in input power and additional savings from controls. For each luminaire type shown, the estimated savings from controls were only applied to the specific luminaires and application areas that are expected to be affected by the controls implementation.

\begin{tabular}{|c|c|c|c|c|c|}
\hline $\begin{array}{c}\text { LUMINAIRE } \\
\text { TYPE }\end{array}$ & $\begin{array}{c}\text { INCUMBENT } \\
\text { ENERGY USE } \\
\mathbf{( k W h )}\end{array}$ & $\begin{array}{c}\text { LED ENERGY } \\
\text { SAVINGS (kWh) }\end{array}$ & $\begin{array}{c}\text { CONTROLS } \\
\text { ENERGY } \\
\text { SAVINGS (kWh) }\end{array}$ & $\begin{array}{c}\text { FINAL ENERGY } \\
\text { USE (kWh) }\end{array}$ & $\begin{array}{c}\text { FINAL ENERGY } \\
\text { SAVINGS (kWh) }\end{array}$ \\
\hline 2x2 Troffer & 240,425 & $57,050(24 \%)$ & $73,350(31 \%)$ & 110,025 & $130,400(54 \%)$ \\
\hline 4' Linear T8 & 171,038 & $72,519(42 \%)$ & $44,437(26 \%)$ & 54,082 & $116,956(68 \%)$ \\
\hline CFL Downlight & 99,400 & $61,025(61 \%)$ & $7,606(8 \%)$ & 30,769 & $68,631(69 \%)$ \\
\hline TOTAL & $\mathbf{5 1 0 , 8 6 3}$ & $\mathbf{1 9 0 , 5 9 4 ( 3 7 \% )}$ & $\mathbf{1 2 5 , 3 9 3 ( \mathbf { 2 5 } \% )}$ & $\mathbf{1 9 4 , 8 7 6}$ & $\mathbf{3 1 5 , 9 8 7}(\mathbf{6 2 \% )}$ \\
\hline
\end{tabular}




\section{Contents}

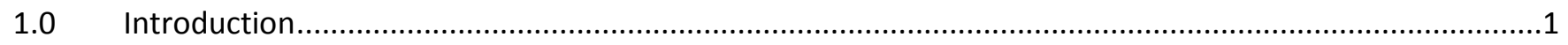

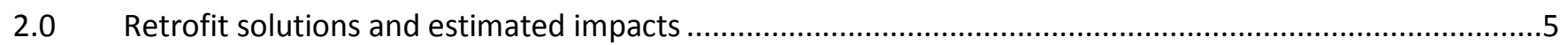

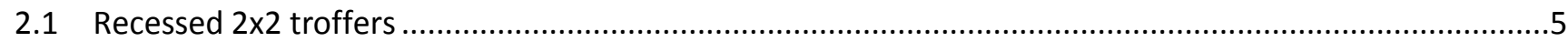

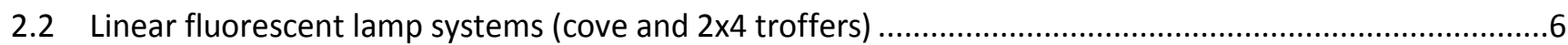

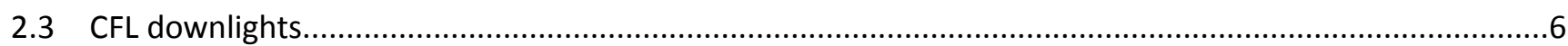

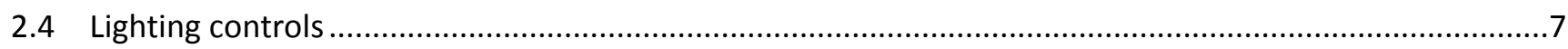

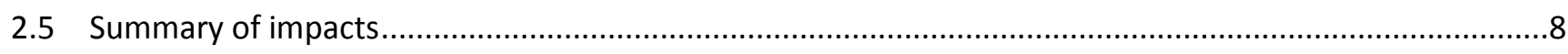

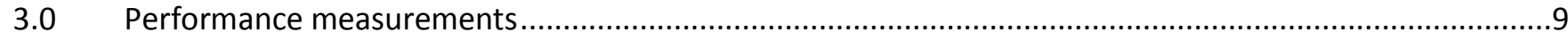

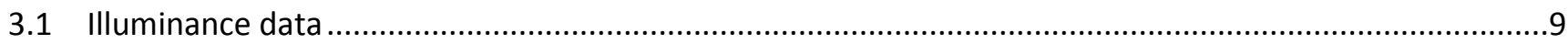

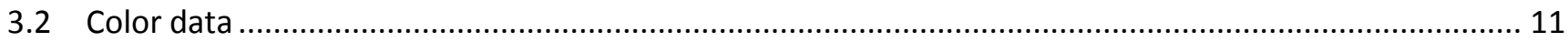

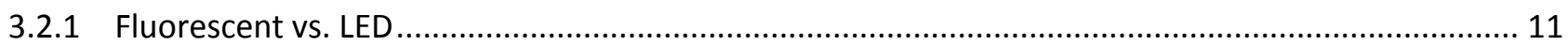

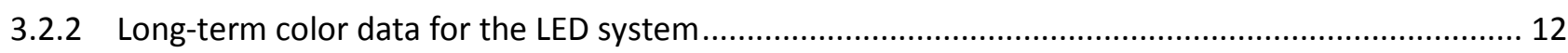

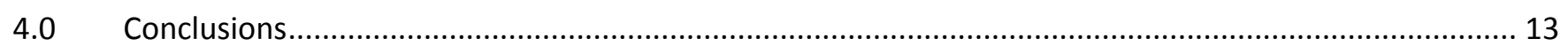




\subsection{Introduction}

Princeton University is the fourth-oldest college or university in the United States and is home to about 6,000 employees and nearly 8,000 students. The university's main campus in Princeton, NJ consists of approximately 180 buildings occupying nine million square feet of space on 500 acres. Princeton established a comprehensive sustainability plan in 2008, which included a commitment to reducing the campus' greenhouse gas emissions to 1990 levels by 2020, without the purchase of market offsets. Reducing the energy used for lighting on campus has been identified as an important step toward achieving this goal. As a result, Princeton is establishing lighting standards for its campus and identifying retrofit solutions for common lighting applications, evaluating them, and then installing them on a campus-wide basis.

While the University has implemented many exterior lighting projects and a few smaller interior projects, ${ }^{4}$ the Carl Icahn Laboratory of the Lewis-Sigler Institute for Integrative Genomics is the first building-wide interior LED project. The Carl Icahn Laboratory is a 98,000 square foot facility, with two separate three-story wings (a basement level plus two above-ground levels) that are connected by a curving, two-story atrium space. The building was designed by Rafael Viñoly and completed in January 2003. The curving two-story glass atrium curtain wall is shielded by 31 external vertical louvers, each 40 feet tall, that automatically rotate with the sun to maximize shade, minimize thermal loading, and reduce cooling load. The computer-controlled aluminum louvers are patterned to project a double-helix DNA-style shadow onto the atrium floor as a dynamic interplay of light and shadow. Figure 1 and Figure 2 show the primary architectural features of the facility.

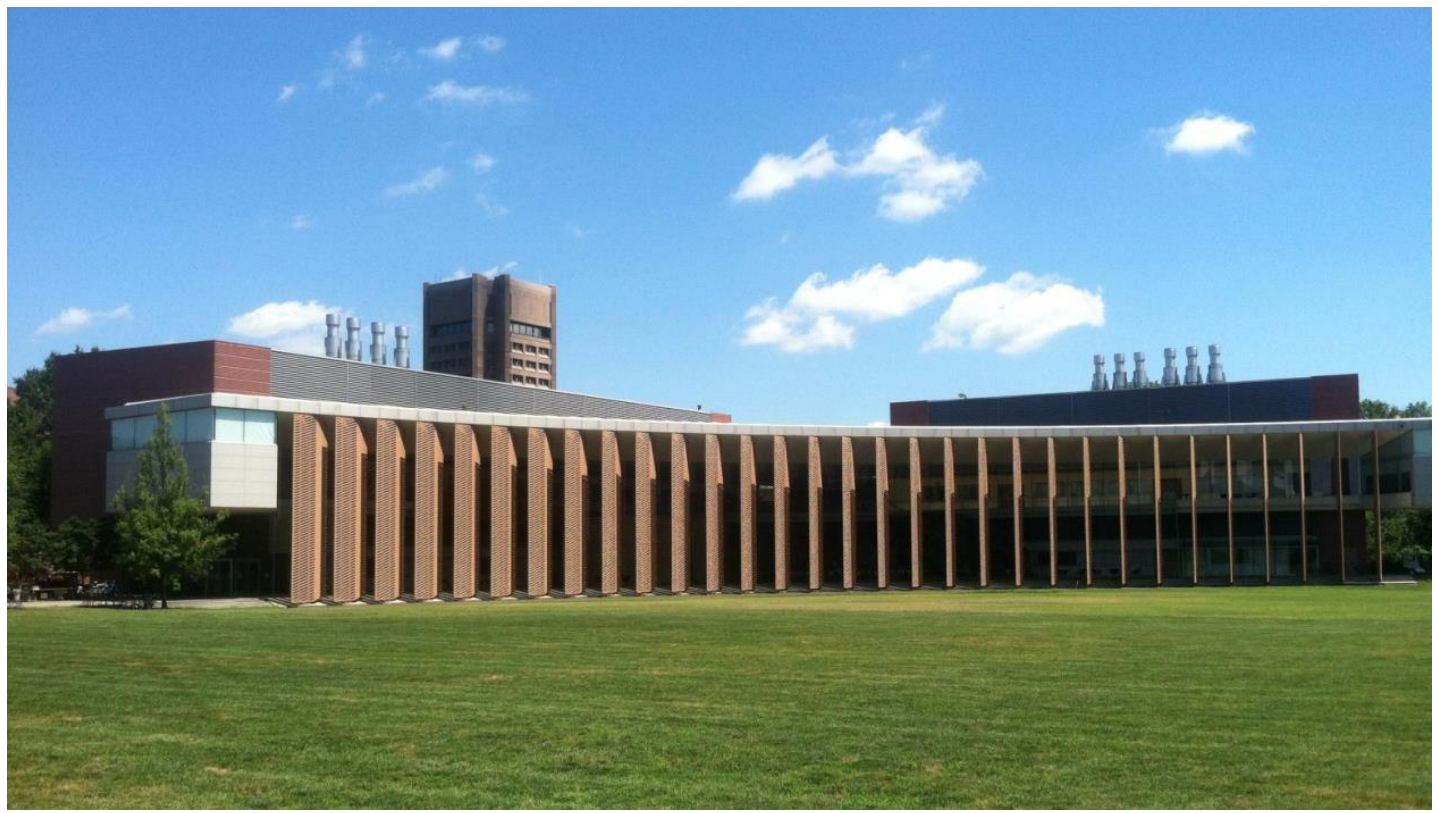

Figure 1: The Carl Icahn Laboratory at Princeton University. The external shade structures are shown at the front of the photo; these devices automatically track the sun to provide shading for the two-story atrium. The two laboratory wings extend above the atrium roof line, one on the north (left side of the photo) and one on the east (right side of the photo).

4 Information and reports related to other projects at Princeton and at other universities may be accessed at the US DOE GATEWAY Program's university web page: http://energy.gov/eere/ssl/gateway-demonstration-university-projects. 

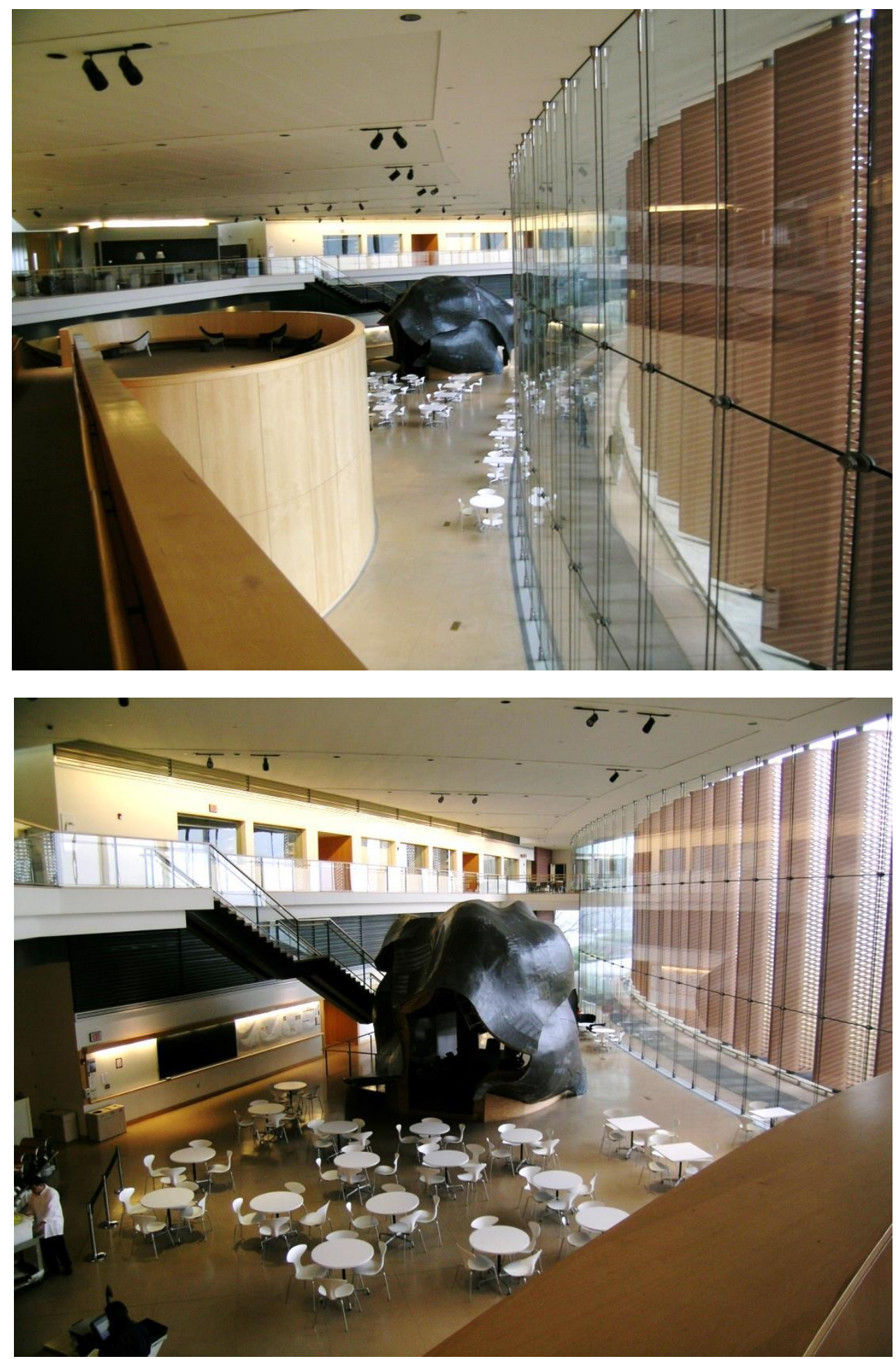

Figure 2: Two photos of the atrium space in Princeton University's Carl Icahn Laboratory, showing the two-story glass curtain wall and the external shading structures. The large sculpture was designed by Frank Gehry, and houses a conference room. The interior walls form the boundary for the laboratory wings, and were originally illuminated with linear fluorescent cove lighting. The fluorescent lamps in these luminaires were replaced with LED retrofit kits.

Most of the original lighting in the laboratory and office spaces consisted of recessed $2 \times 2$ fluorescent troffers, with supplemental linear fluorescent cove lighting in perimeter areas and a relatively small number of recessed $2 \times 4$ fluorescent troffers. Of the 564,000 kWh of energy used annually for lighting in the facility, about $43 \%$ was from the $2 \times 2$ fixtures and $30 \%$ from the 4 ' linear lamp fixtures. Figure 3 shows a typical lab space, with the 
recessed troffers providing most of the lighting in the open lab bench areas and the linear fluorescent cove luminaires used along the perimeter. The third largest lighting energy use came from recessed and surfacemounted downlights using compact fluorescent lamps (CFLs); these luminaires were used in lobby and corridor areas and accounted for about $18 \%$ of the lighting energy used in the facility.

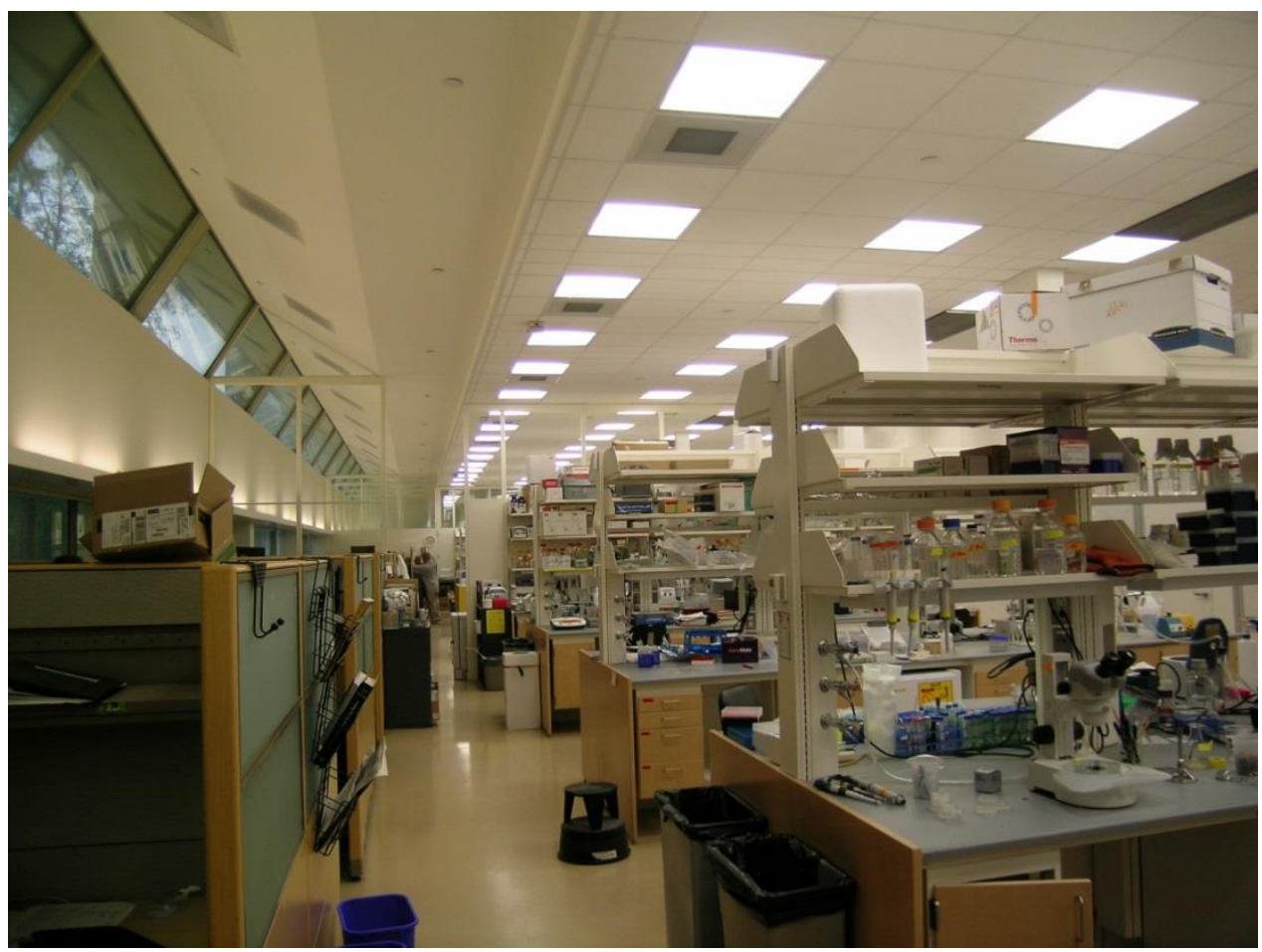

Figure 3: Laboratory space in the Carl Icahn Laboratory, showing the recessed $2 \times 2$ fluorescent troffers and the linear fluorescent cove fixtures along the perimeter.

Because of the age and operations of the lighting systems in the Carl Icahn Laboratory, an upgrade to the incumbent systems provided several important opportunities for Princeton:

- Energy savings and the associated carbon reduction. Replacing the incumbent light sources with higher efficacy options such as LED provided the opportunity for substantial energy savings, especially when coupled with the installation of intelligent controls. These energy savings translate directly to Princeton's carbon reduction goals.

- Maintenance and operational cost savings. The fluorescent U-lamps used in the recessed troffers are relatively expensive lamps with very limited options for direct replacement. The rated lifetimes of the CFLs used in the downlights are relatively short, requiring regular replacement given the long annual operating hours for the corridors and lobby areas where they are used. Given the fact that all of the incumbent luminaires and ballasts were installed in 2003, the frequency with which the ballasts need to be replaced was expected to increase over the next few years. These factors all indicated that a buildingwide lighting upgrade would produce substantial savings in maintenance and operational costs.

- Implementation of intelligent controls for occupancy and dimming. The incumbent luminaires in the open lab spaces, both the recessed $2 \times 2$ and cove luminaires, are controlled by relatively few wall switches. As a result, since each switch controls a large zone of luminaires, large areas are illuminated whenever the lab space is occupied, even if the occupancy consists of just a single individual in a small area. Unless the last person leaving a lab space makes an effort to locate the switch and turn the lights off, they remain on during hours when there is no occupancy. Furthermore, while the lab benches 
themselves require relatively high illuminances for the tasks performed there, corridors and other less task-intensive areas do not require the same illuminances and were over lit with the incumbent system. The LED retrofit solutions chosen for the facility provided opportunities for combining occupancy and dimming control to extend the energy savings beyond that provided by the increased efficacy of the new systems.

- Improvements in lighting quality. As is typical of many fluorescent lighting systems which have been in place for more than 10 years, the color quality of the incumbent fluorescent system was a mixture of various correlated color temperatures (CCTs) and color rendering indices (CRIs). Upgrading to an LED system provided the opportunity to achieve more consistent color quality throughout the facility, in many cases reducing the variation in CCT and increasing the CRI values relative to the incumbent system.

The LED retrofit project at the Carl Icahn Laboratory addressed each of these opportunities in the three primary luminaire types by replacing the incumbent fluorescent lamps with LED retrofit products. In addition, the conversion to LED enabled more extensive use of lighting controls to tailor the lighting to the task and limit the operating hours based on occupancy. Section 2.0 provides the details of the retrofit solutions selected and the resulting energy savings, and Section 3.0 summarizes the performance data on the incumbent and retrofit systems, measured before and after the LED conversion. 


\subsection{Retrofit solutions and estimated impacts}

As the first step in the retrofit project at the Carl Icahn Laboratory, a detailed energy audit of the building lighting system was conducted in July 2013, during which the usage and the type and quantity of luminaires present in every room in the facility were recorded. The lamp types used and the rated fixture input power for each luminaire type were verified during the audit. Operating hours for different spaces and luminaires throughout the building were also estimated. Based on the results of the audit, the annual energy used for lighting in the Carl Icahn Laboratory was estimated to be $563,631 \mathrm{kWh}$. Over $90 \%$ of this energy was devoted to three luminaire / lamp types, as shown in Figure 4. These three categories became the targets for the lighting upgrade project.

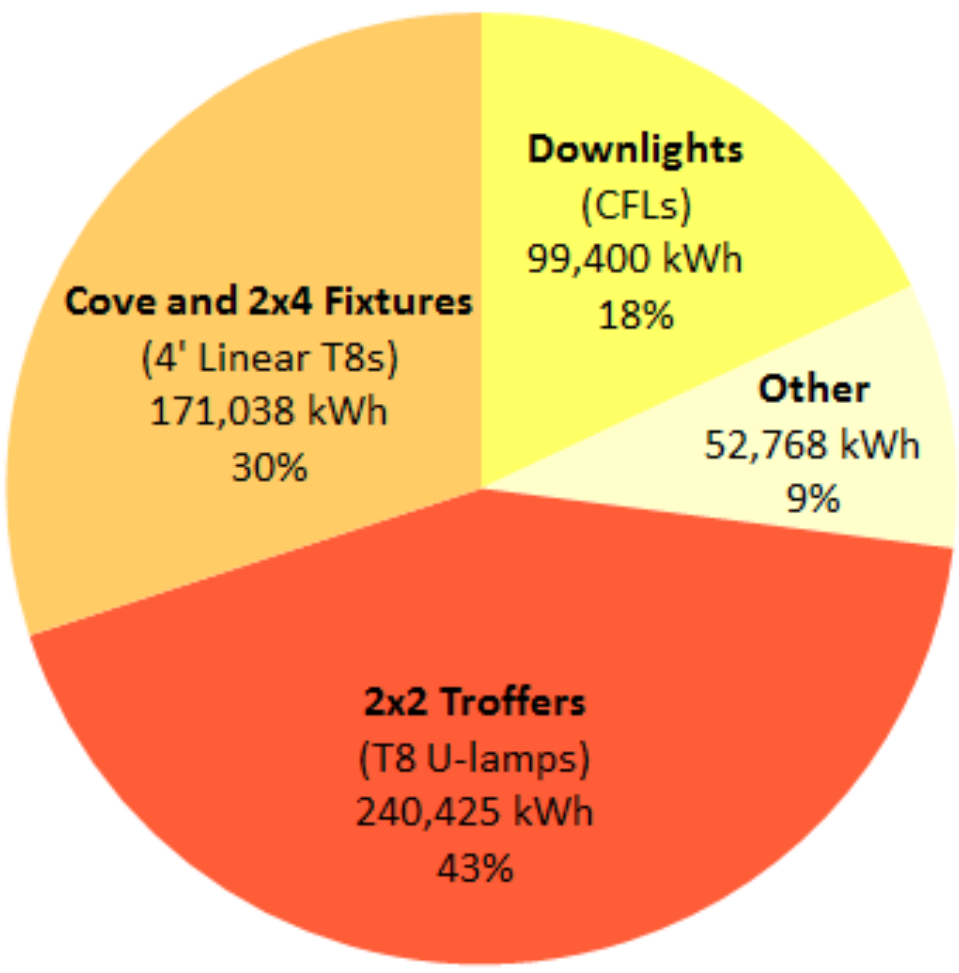

Figure 4: Estimated annual energy used by the major incumbent luminaire types in the Carl Icahn Laboratory.

\subsection{Recessed $2 \times 2$ troffers}

The incumbent lighting system in most of the lab and office spaces was comprised of 815 recessed $2 \times 2$ luminaires. Each of these luminaires had an acrylic prismatic lens, used two $31 \mathrm{~W}$ T8 fluorescent U-lamps with an electronic ballast for total input power of $59 \mathrm{~W}$, and operated for an estimated 5,000 hours per year.

The Princeton facilities engineering staff evaluated products from five different manufacturers for the $2 \times 2$ luminaire retrofit, with quoted prices ranging from about $\$ 75$ to over $\$ 200$ per unit. Based on an initial evaluation of the performance attributes as well as price and warranty considerations, three of the retrofit products were selected for further assessment. Multiple samples of those products were installed in the building, where they were evaluated by various stakeholders for such considerations as appearance, perceived impacts on light levels and distribution, and potential glare. 
The outcome of this evaluation process was the selection of a MaxLite ${ }^{\circledR}$ LED retrofit kit that provides 3315 lumens at $45 \mathrm{~W}$ power input, with a CCT of $4100 \mathrm{~K}$ and minimum CRI of 82 . The kit carries a safety certification from ETL and is on the DesignLights Consortium's ${ }^{\mathrm{TM}}$ (DLC) Qualified Products List (QPL). For the $2 \times 2$ fixtures, the MaxLite retrofit kit reduces the per-fixture wattage from $59 \mathrm{~W}$ to $45 \mathrm{~W}$, for annual energy savings of over 57,000 kWh.

The MaxLite kit was selected based on positive assessments during the mockup, substantial reduction in connected power relative to the existing system, favorable pricing and warranty terms, the ability to integrate well with the planned lighting control system, and provision of 0-10 V dimming with the capability to turn the power completely off at the $0 \mathrm{~V}$ setting. Other retrofit products evaluated did not shut off at the $0 \mathrm{~V}$ setting, requiring additional wiring and labor to enable complete power off, adding substantially to the installation cost. This was a key consideration in the selection of the MaxLite units.

\subsection{Linear fluorescent lamp systems (cove and $2 \times 4$ troffers)}

The Icahn Lab also has linear fluorescent cove lighting and some $2 \times 4$ recessed troffers, mostly using 4' 32 W T8 lamps. The applications for these luminaires range from perimeter cove lighting (5,000 hours of annual use), to office lighting (3,500 hours), to corridor and elevator lighting (8,760 hours), to closet and mailroom lighting (1,500 - 3,000 hours). For the upgrade project, more than 550 of these luminaires were retrofitted with the Cree UR Series retrofit kit that replaces the lamps and ballasts, providing 4500 lumens at $44 \mathrm{~W}$ input power, with a CCT of $4000 \mathrm{~K}$ and a CRI of 80. Each kit replaces two T8 lamps. The UR Series kits are UL-classified as retrofit kits and are on the DLC's QPL. The facilities engineering staff selected the UR Series product based on favorable experiences in several prior small-scale retrofit projects in other buildings on campus. For the 4' linear lamp fixtures, annual energy savings were estimated to be over $111,000 \mathrm{kWh}$.

\subsection{CFL downlights}

Many of the corridors, lobby areas, and conference areas in the Carl Icahn Laboratory have downlights. The most common downlight in the facility used two $42 \mathrm{~W}$ CFLs, which posed a challenge for LED retrofit products due to the relatively high light output (each CFL is rated to produce 3200 lumens). Princeton evaluated several options for these luminaires through mock-ups and review of technical information, with most of the alternates failing to meet the light output requirements. Ultimately, the TerraLux DR8 retrofit kit was selected, and two other TerraLux products were then selected for the other, lower light output downlights in the facility. The downlight retrofit solutions chosen were:

- For the 205 round downlights with 8" diameter, the TerraLux DR8 LED retrofit kit was installed. This 34 W kit produces 2935 lumens and reduced the luminaire input power from $88 \mathrm{~W}$, replacing two $42 \mathrm{~W}$ CFLs and the ballast.

- For the 15 round downlights with 6" diameter, the TerraLux DR6 LED retrofit kit was installed. This retrofit kit produces 1675 lumens and reduced the luminaire input power from $36 \mathrm{~W}$ to $17 \mathrm{~W}$.

- For the 25 square surface-mounted downlights, the TerraLux SR95 LED retrofit kit was installed. This retrofit kit produces 1924 lumens and reduced the luminaire input power from $52 \mathrm{~W}$ to $18 \mathrm{~W}$.

Together, the incumbent downlights use just under $100,000 \mathrm{kWh}$ annually, roughly $18 \%$ of the total lighting energy for the facility. The LED solutions are estimated to save over $61,000 \mathrm{kWh}$ annually. 


\subsection{Lighting controls}

The incumbent recessed $2 \times 2$ and cove luminaires in the open lab spaces were controlled by relatively few wall switches that control large zones of luminaires. As a result, large areas were fully illuminated whenever the lab space was occupied, even if the occupancy consisted of just a single individual working in a small area, and the lighting remained on if the occupant did not turn them off upon leaving. Individual enclosed lab and office spaces typically each have a single wall switch controlling all of the luminaires in each space. Based on the control configurations for the incumbent systems, Princeton decided to implement wireless occupancy sensor controls that would address smaller zones of luminaires, enabling further energy savings through dimming or turning off luminaires in zones where there was no occupancy detected. The occupancy sensors were also integrated with the building's HVAC system, extending the energy savings by also reducing the HVAC energy use during periods of low or no occupancy.

In addition to the occupancy-based lighting controls, the ability to dim the LED retrofit kits for the $2 \times 2$ luminaires enabled further savings by allowing the illuminance levels in spaces to be adjusted to meet specific task needs. Laboratory bench work requires relatively high illuminance levels, while other areas such as corridors and conference areas have lower recommended illuminances. The incumbent $2 \times 2$ recessed troffer system provided high illuminances regardless of the task, so the dimming functionality of the LED system provided the opportunity for the output of the converted luminaires to be "trimmed" to meet the specific lighting needs within different areas in the facility.

Based on previous project experiences, the university estimated that the combination of the occupancy and task-tuning dimming control strategies would reduce the energy use of the affected luminaires by an additional $40 \%$, beyond the reduction resulting from the reduced LED wattage. In the analyses conducted for the building, those savings were assumed to apply to all of the spaces illuminated by the $2 \times 2$ luminaires. The spaces using the linear fluorescent and CFL luminaires were evaluated individually, and the control savings estimates were only included for those spaces where occupancy and dimming control were expected to yield additional savings. For example, the control savings estimates were applied for downlights used in restrooms and offices where occupancy sensors were planned, but not in corridors, since occupancy-based switching was not planned for corridors. This resulted in just over half of the downlight luminaires being affected by the controls. For the linear fluorescent luminaires, $29 \%$ were in spaces where occupancy control would occur. Additionally, the light output for most of the linear luminaires $(77 \%)$ was planned to be restricted to $50 \%$ of the maximum possible $(50 \%$ highend trim), since the IES recommended illuminance levels could be satisfied in these spaces with the linear LED products operating at reduced output.

At the time of this report, although all of the LED retrofit products had been installed and operational for several months, the control system had not yet been completely deployed and commissioned. The delays in deployment were in part related to concerns about possible interactions of the wireless sensors and related data with the university's networks, and in part to ongoing education and discussions with the laboratory staff about the operation of the occupancy controls. Because the laboratory work taking place in the facility sometimes involves handling of hazardous chemicals, implementing occupancy-based lighting controls is proceeding with great care to ensure that sudden changes in light output do not occur while a researcher is in the midst of working with such materials. 


\subsection{Summary of impacts}

Table 1 shows the estimated energy savings for the LED retrofit project for each luminaire type, without any additional savings from controls. As shown, upgrading the three primary luminaire types is estimated to reduce the annual lighting energy use for the facility from $510,863 \mathrm{kWh}$ to $320,269 \mathrm{kWh}$, a savings of $37 \%$.

Table 1: Estimated energy savings for the LED retrofit project at the Carl Icahn Laboratory. The savings shown are based on the reductions in input power for the LED products, assuming the same operating hours and no additional savings from controls.

\begin{tabular}{|c|c|c|c|}
\hline LUMINAIRE TYPE & $\begin{array}{c}\text { INCUMBENT } \\
\text { ENERGY USE (kWh) }\end{array}$ & $\begin{array}{c}\text { LED RETROFIT } \\
\text { ENERGY USE (kWh) }\end{array}$ & $\begin{array}{c}\text { ANNUAL ENERGY } \\
\text { SAVINGS (kWh) }\end{array}$ \\
\hline $2 \times 2$ Troffer & 240,425 & 183,375 & $57,050(24 \%)$ \\
\hline 4 ' Linear T8 & 171,038 & 98,519 & $72,519(42 \%)$ \\
\hline CFL Downlight & 99,400 & 38,375 & $61,025(61 \%)$ \\
\hline TOTAL & $\mathbf{5 1 0 , 8 6 3}$ & $\mathbf{3 2 0 , 2 6 9}$ & $\mathbf{1 9 0 , 5 9 4 ( 3 7 \% )}$ \\
\hline
\end{tabular}

Because the $2 \times 2$ troffers are used throughout areas where the controls strategies are implemented, this luminaire type has the greatest additional savings from controls. The other luminaire types are used in some application areas where the controls are implemented and in other areas where the existing controls remain in place, so the estimated additional savings were only applied to the relevant areas. Table 2 shows the estimated energy savings for the facility, with the additional savings expected from full implementation of the controls strategies. As shown, the estimated energy savings including controls is $62 \%$ compared to the incumbent system. Although the specific costs and financial details of the project are confidential, the project is expected to yield a simple payback of less than four years. Additionally, the energy savings from the lighting retrofit is estimated to avoid about 100 metric tons of carbon dioxide emissions, an important consideration in Princeton's energy management efforts.

Table 2: Estimated energy savings for the LED retrofit project at the Carl Icahn Laboratory, including reductions in input power and additional savings from controls. For each luminaire type shown, the estimated savings from controls were only applied to the specific luminaires and application areas that are expected to be affected by the controls implementation.

\begin{tabular}{|c|c|c|c|c|c|}
\hline $\begin{array}{c}\text { LUMINAIRE } \\
\text { TYPE }\end{array}$ & $\begin{array}{c}\text { INCUMBENT } \\
\text { ENERGY USE } \\
\mathbf{( k W h )}\end{array}$ & $\begin{array}{c}\text { LED ENERGY } \\
\text { SAVINGS (kWh) }\end{array}$ & $\begin{array}{c}\text { CONTROLS } \\
\text { ENERGY } \\
\text { SAVINGS (kWh) }\end{array}$ & $\begin{array}{c}\text { FINAL ENERGY } \\
\text { USE (kWh) }\end{array}$ & $\begin{array}{c}\text { FINAL ENERGY } \\
\text { SAVINGS (kWh) }\end{array}$ \\
\hline $2 \times 2$ Troffer & $\mathbf{2 4 0 , 4 2 5}$ & $57,050(\mathbf{2 4 \% )}$ & $73,350(31 \%)$ & 110,025 & $130,400(54 \%)$ \\
\hline $4^{\prime}$ Linear T8 & 171,038 & $72,519(\mathbf{4 2 \% )}$ & $44,437(26 \%)$ & 54,082 & $116,956(68 \%)$ \\
\hline CFL Downlight & 99,400 & $61,025(61 \%)$ & $7,606(8 \%)$ & 30,769 & $68,631(69 \%)$ \\
\hline TOTAL & $\mathbf{5 1 0 , 8 6 3}$ & $\mathbf{1 9 0 , 5 9 4 ( 3 7 \% )}$ & $\mathbf{1 2 5 , 3 9 3 ( \mathbf { 2 5 } \% )}$ & $\mathbf{1 9 4 , 8 7 6}$ & $\mathbf{3 1 5 , 9 8 7}(\mathbf{6 2 \% )}$ \\
\hline
\end{tabular}




\subsection{Performance measurements}

PNNL staff visited the facility in January 2014 to document the existing conditions and to measure illuminance and color performance for the incumbent fluorescent recessed $2 \times 2$ troffer and linear T8 systems. Three areas of the building were chosen for analysis:

- Room 222, an enclosed lab space that was empty at the time of the data collection. The room is $10.5 \mathrm{ft}$ wide by $22.1 \mathrm{ft}$ long, with a ceiling height of $11.5 \mathrm{ft}$. The lighting consists of eight $2 \times 2$ recessed luminaires with prismatic lenses, typical of the $2 \times 2 \mathrm{~s}$ used throughout the facility.

- Corridor 233, at the eastern end of the second floor of the west wing. Four recessed $2 \times 2$ luminaires are located in this corridor area.

- Lab Area 110, an open lab space including a lab bench and work cubicles. The lighting in the open lab area consists of $2 \times 2$ luminaires, while the linear cove luminaires are located above the cubicles. (See Figure 3.)

After the LED retrofit of the troffers and linear lamps was completed, the illuminance and color measurements were repeated in these same areas in October 2014. A third site visit occurred in April 2015 to evaluate the color stability of the LED system over the first six months of operation.

To evaluate the LED retrofit of the CFL downlights, illuminance and color data of the LED retrofit system were measured for an open conference area on the second floor balcony (designated 200 COR). Initial readings were taken during the October 2014 visit and the color measurements were repeated during the April 2015 visit.

\subsection{Illuminance data ${ }^{5}$}

The average illuminances produced by the fluorescent system and the LED system in Room 222, Corridor 233, and Lab Area 110 are shown in Table 3, and Figure 5 provides photos of each area. Any changes in the distribution and uniformity of illuminance were minor, based on an evaluation of measured uniformity ratios (where applicable). The data show that the LED solutions are providing more light than the incumbent fluorescent systems; in most cases, much more light. Since the fluorescent lamps were of unknown age at the time of the measurements, the incumbent systems had experienced some degree of normal lamp lumen depreciation, but that depreciation for the incumbent lamp types would normally be no greater than about $15 \%$. Even assuming worst-case depreciation for the fluorescent systems, the LED illuminance values still exceeded the fluorescent system values. Once the lighting control system is fully implemented, the facility management staff plan to dim the LED system in areas where the illuminances exceed the task needs, harvesting further energy savings through this task-tuned dimming.

5 Illuminance readings were measured using a calibrated Konica Minolta T-10A illuminance meter. 


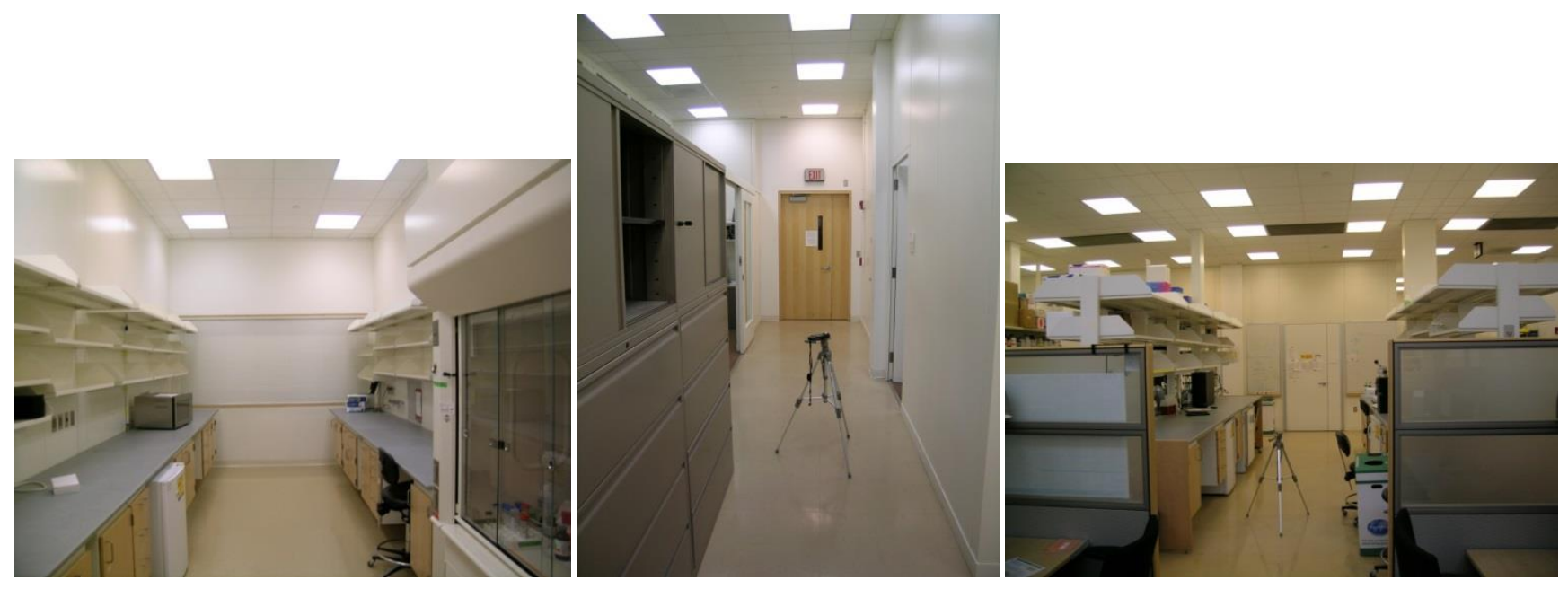

Figure 5: Room 222 (left), Corridor 233 (center), and Lab Area 110 (right).

Table 3: Average illuminances ( $\mathrm{fc}$ ) in the Carl Icahn Laboratory for the incumbent fluorescent and retrofit LED systems. An (H) designation indicates horizontal illuminance values and a (V) designation indicates vertical illuminance values. The fluorescent data were collected in January 2014 and the LED data were collected in October 2014. The reported illuminances do not include any contributions from daylight, which is usually substantial in the cubicle and open lab areas during the day.

\begin{tabular}{|c|c|c|c|}
\hline \multicolumn{2}{|c|}{ LOCATION } & $\begin{array}{c}\text { FLUORESCENT } \\
\text { (Average illuminance } \\
\text { for points measured, } \\
\text { fc) }\end{array}$ & $\begin{array}{c}\text { LED } \\
\text { (Average } \\
\text { illuminance for } \\
\text { points measured, fc) }\end{array}$ \\
\hline \multirow{3}{*}{ Room 222 } & Grid at 3' AFF (H) & 62 & 104 \\
\cline { 2 - 4 } & Top of window (V) & 57 & 86 \\
\cline { 2 - 4 } & Front of top shelf (H) & 92 & 149 \\
\hline \multirow{2}{*}{$\begin{array}{c}\text { Corridor } \\
233\end{array}$} & Front of top shelf (V) & 41 & 66 \\
\hline \multirow{2}{*}{$\begin{array}{c}\text { Lab Area } \\
110\end{array}$} & Centerline of luminaires at 3' AFF (H) & 53 & 57 \\
\cline { 2 - 4 } & South wall at 5' AFF (V) & 30 & 86 \\
\hline
\end{tabular}

To evaluate the performance of the CFL downlights that were converted using LED retrofit kits, illuminances in an open conference area (200 COR) were measured in October 2014, after the LED retrofit had occurred. (An evaluation of the CFL system before the conversion was not possible due to scheduling difficulties.) A photograph of this area is provided in Figure 6. Horizontal illuminances were measured on a grid across the conference table, with an average of $54 \mathrm{fc}$ and a max-to-min uniformity ratio of 1.3. To assess the illuminance on faces during a conference session, vertical illuminances were measured at points around the perimeter of the table where people would be seated; the average vertical illuminance was $18 \mathrm{fc}$ with a max-to-min uniformity ratio of 1.2. These values satisfy IES recommended values for conference areas. 


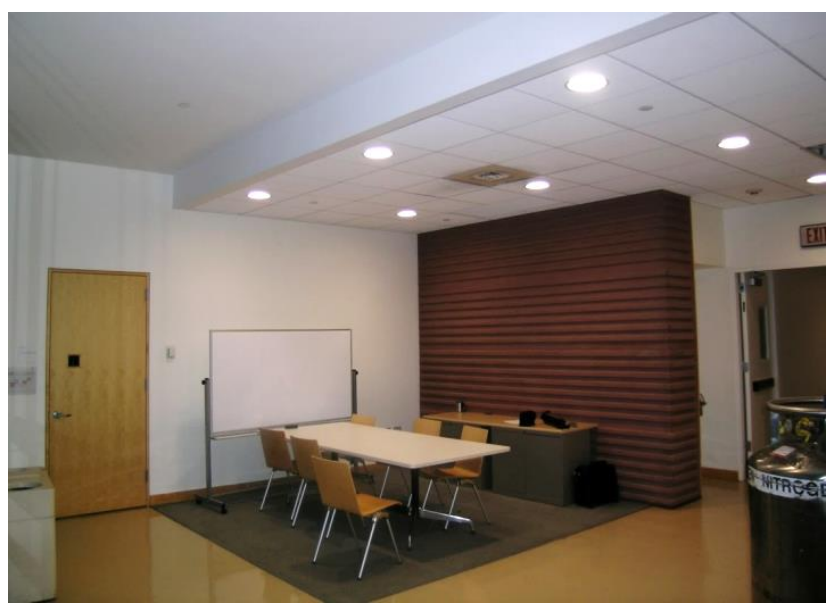

Figure 6: Conference area 200 COR, showing the downlights that were converted from CFL to LED.

\subsection{Color data ${ }^{6}$}

\subsubsection{Fluorescent vs. LED}

To compare the color quality of the incumbent fluorescent $2 \times 2$ system with the post-retrofit LED system, the CCT and CRI of the seven accessible luminaires in Room 22 were measured in January 2014 for the fluorescent and then again in October 2014 for the LED system. There were noticeable color differences in the fluorescent system throughout the facility, including in Room 222, most likely due to burned-out lamps being replaced with new lamps of various CCTs (an unfortunate reality in many fluorescent lighting systems). Table 4 shows the measured color data for the luminaires in Room 222. As shown, the CCTs for the fluorescent system varied between $2842 \mathrm{~K}$ and $3750 \mathrm{~K}$, a range of over $900 \mathrm{~K}$, while the LED luminaires varied between $4299 \mathrm{~K}$ and $4336 \mathrm{~K}$, a range of just $37 \mathrm{~K}$. The $\mathrm{CRI}$ for five of the seven fluorescent luminaires was less than 80 , while all seven of the CRI values for the LED system were 85 .

Table 4: Color data for the incumbent fluorescent system vs. the converted LED system in Room 222.

\begin{tabular}{|c|c|c|c|c|}
\hline \multirow{2}{*}{ LUMINAIRE } & \multicolumn{2}{|c|}{ FLUORESCENT } & \multicolumn{2}{c|}{ LED } \\
\cline { 2 - 5 } & CCT (K) & CRI & 4304 & CRI \\
\hline $222-1$ & 3715 & 81 & 4336 & 85 \\
\hline $222-2$ & 3169 & 77 & 4323 & 85 \\
\hline $222-3$ & 2842 & 86 & 4303 & 85 \\
\hline $222-4$ & 3747 & 78 & 4311 & 85 \\
\hline $222-5$ & 3746 & 78 & 4313 & 85 \\
\hline $222-6$ & 3750 & 78 & 4299 & 85 \\
\hline $222-7$ & 3158 & 78 & $\mathbf{4 3 1 3}$ & $\mathbf{8 5}$ \\
\hline Avg & $\mathbf{3 4 4 7}$ & $\mathbf{7 9}$ & $\mathbf{3 7}$ & $\mathbf{0}$ \\
\hline Range & $\mathbf{9 0 8}$ & $\mathbf{9}$ & & \\
\hline
\end{tabular}

6 Color measurements were made using a calibrated Konica Minolta CL-500A illuminance spectrophotometer. 


\subsubsection{Long-term color data for the LED system}

Because they are a relatively new technology, one concern about LED products is how they will maintain their performance over time. In order to track one aspect of long-term performance, the color properties of the LED products in the Carl Icahn Laboratory are being measured periodically. Table 5 shows the measured color data for 10 of the LED-converted troffer luminaires and for seven of the LED downlights, from October 2014 and April 2015. The estimated operating hours between the two measurements was 2500 hours. A change in CCT represents a relative shift along the blackbody curve in a standard chromaticity diagram, which perceptually follows a blue-yellow (cool-warm) axis. The $D_{u v}$ value shows the distance of the chromaticity coordinates from the blackbody curve, with positive values located above the curve and negative values located below the curve. A change in $D_{u v}$ represents a perceptual shift along a red-green axis. For the products evaluated, the changes in $C C T$ and $D_{u v}$ are very small and would not be detectable in normal viewing conditions. The $\Delta u^{\prime} v^{\prime}$ values, which express the amount of color shift between the two measurement dates, were no greater than 0.001 , showing that the color properties have remained very stable during this initial period. (For reference, Energy Star requires $\Delta u^{\prime} v^{\prime}$ to be less than 0.007 after 6000 hours.) The color properties of the LED products evaluated have remained very stable during the initial six month period.

Table 5: Long-term color data for the LED retrofit products in the troffers and downlights. Seven troffers in Room 222 and three troffers in Corridor $\mathbf{2 3 3}$ were evaluated, as well as seven downlights in Conference Area 200 COR.

\begin{tabular}{|c|c|c|c|c|c|c|}
\hline \multirow{2}{*}{\multicolumn{2}{|c|}{ LOCATION }} & \multicolumn{2}{|c|}{ LED - OCT 2014} & \multicolumn{2}{|c|}{ LED - APR 2015} & \multirow{2}{*}{$\Delta u^{\prime} v^{\prime}$} \\
\hline & & CCT (K) & $D_{u v}$ & СCT (K) & $D_{u v}$ & \\
\hline \multirow{7}{*}{ Room 222} & Troffer 222-1 & 4304 & -0.003 & 4351 & -0.003 & 0.001 \\
\hline & Troffer 222-2 & 4336 & -0.003 & 4386 & -0.003 & 0.001 \\
\hline & Troffer 222-3 & 4323 & -0.003 & 4355 & -0.003 & 0.001 \\
\hline & Troffer 222-4 & 4303 & -0.003 & 4328 & -0.003 & 0.001 \\
\hline & Troffer 222-5 & 4311 & -0.003 & 4349 & -0.003 & 0.001 \\
\hline & Troffer 222-6 & 4313 & -0.004 & 4345 & -0.004 & 0.001 \\
\hline & Troffer 222-7 & 4299 & -0.003 & 4336 & -0.003 & 0.001 \\
\hline \multirow{3}{*}{ Corridor 233} & Troffer 233-1 & 4386 & -0.003 & 4398 & -0.003 & 0.000 \\
\hline & Troffer 233-2 & 4398 & -0.004 & 4399 & -0.004 & 0.000 \\
\hline & Troffer 233-4 & 4309 & -0.004 & 4310 & -0.004 & 0.000 \\
\hline \multirow{7}{*}{$\begin{array}{c}\text { Conference Area } \\
200 \text { COR }\end{array}$} & Downlight 200-1 & 3498 & -0.004 & 3484 & -0.003 & 0.001 \\
\hline & Downlight $200-2$ & 3493 & -0.004 & 3483 & -0.003 & 0.001 \\
\hline & Downlight 200-3 & 3497 & -0.004 & 3483 & -0.003 & 0.001 \\
\hline & Downlight 200-4 & 3503 & -0.003 & 3497 & -0.003 & 0.001 \\
\hline & Downlight 200-5 & 3504 & -0.004 & 3486 & -0.003 & 0.001 \\
\hline & Downlight $200-6$ & 3500 & -0.004 & 3493 & -0.003 & 0.001 \\
\hline & Downlight 200-7 & 3475 & -0.004 & 3471 & -0.003 & 0.001 \\
\hline
\end{tabular}




\subsection{Conclusions}

The LED lighting retrofit at the Carl Icahn Laboratory of the Lewis-Sigler Institute for Integrative Genomics was the first building-wide interior LED project at Princeton University, following the University's experiences from several years of exterior and small-scale interior LED implementation projects. The project addressed three luminaire types - recessed $2 \times 2$ troffers, cove and other luminaires using linear T8 fluorescent lamps, and CFL downlights - which combined accounted for over $564,000 \mathrm{kWh}$ of annual energy, over $90 \%$ of the lighting energy used in the facility. The Princeton Facilities Engineering staff used a thorough process of evaluating product alternatives before selecting an acceptable LED retrofit solution for each luminaire type. Overall, 815 2x2 luminaires, 550 linear fluorescent luminaires, and 240 downlights were converted to LED as part of this project.

Based solely on the reductions in wattage in converting from the incumbent fluorescent lamps to LED retrofit kits, the annual energy savings from the project was over $190,000 \mathrm{kWh}$, a savings of $37 \%$. An additional 125,000 kWh of energy savings is expected from the implementation of occupancy and task-tuning control solutions, which will bring the total savings for the project to $62 \%$. The ability to task-tune the LED system provides great flexibility in a laboratory setting, allowing the facility manager to adjust the output (and reduce the energy use) of the luminaires to match the specific needs in diverse spaces such as lab benches, corridors, and office cubicles.

While the installation of the LED retrofit kits in the different luminaire types was relatively straightforward, full deployment of the control solution has proven to be more difficult. Concerns about network reliability and security when building controls systems using wireless communication protocols are embedded into a larger network infrastructure have become more common, and Princeton is no exception. The extended coordination and information exchange required between facilities staff, information technology experts, manufacturers, and manufacturers' representatives can extend the time for full implementation well beyond what was initially anticipated. The further need for addressing concerns of the facility end users about new occupancy-based controls also has delayed in controls implementation at the Carl Icahn Lab.

Site measurements of illuminance levels and color properties show that the LED retrofits are performing well in the facility, meeting or exceeding the performance of the incumbent systems and IESNA requirements. The LED lighting systems at the Carl Icahn Laboratory are using significantly less energy than the incumbent fluorescent system used, and the energy use for the lighting in the facility will be reduced even further once the lighting controls are fully implemented. The project met the University's economic requirements, and is contributing to Princeton's overall carbon reduction goals. 


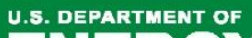 ENERCY}

Energy Efficiency \& Renewable Energy
For more information, visit: www.energy.gov 